\title{
Elephants - a conservation overview
}

\author{
Heidi S. Riddle' ${ }^{1}$, Bruce A. Schulte ${ }^{2}$, Ajay A. Desai ${ }^{3}$, Laura van der Meer ${ }^{4}$ \\ ${ }^{1}$ Riddle's Elephant and Wildlife Sanctuary, PO Box 715, Greenbrier, Arkansas 72058, USA \\ ${ }^{2}$ Department of Biology, Western Kentucky University, Bowling Green, Kentucky 42101, USA \\ ${ }^{3}$ B.C. 84 Camp, Belgaum, Karnataka 590001, India \\ ${ }^{4}$ International Environmental Resources, B-1380 Lasne, Belgium \\ Email: ${ }^{1}$ gajah@windstream.net
}

Date of publication (online): 26 January 2010 Date of publication (print): 26 January 2010 ISSN 0974-7907 (online) | 0974-7893 (print)

Editor: Thomas Husband

\section{Manuscript details:}

Ms \# 02024

Received 23 July 2008

Final received 22 July 2009

Finally accepted 12 November 2009

Citation: Riddle, H.S., B.A. Schulte, A.A. Desai, L. van der Meer (2009). Elephants - a conservation overview. Journal of Threatened Taxa 2(1): 653 661.

Copyright: (C) Heidi S. Riddle, Bruce A. Schulte, Ajay A. Desai, Laura van der Meer 2009. Creative Commons Attribution 3.0 Unported License. JoTT allows unrestricted use of this article in any medium for non-profit purposes, reproduction and distribution by providing adequate credit to the authors and the source of publication.

Author Details: HeIDI S. RIDDLE is co-founder of Riddle's Elephant and Wildlife Sanctuary, USA. She facilitates elephant management via education and study, and advises conservation organizations. She is a member of the IUCN SSC Asian Elephant, and Conservation Breeding Specialist Groups.

Bruce A. Schulte is a Professor and Departmen Head of Biology at Western Kentucky University, USA. He is actively involved in elephant studies, and takes part in field projects in Africa. Along with collaborators and students, Bruce examines behavioral questions on wild and captive elephants.

AJAY A. DESAI is a wildlife biologist specialized in Asian elephants through studies on behavior, ecology, and conservation. He consults for conservation projects in Asian elephant range countries. He is co-Chair of the IUCN SSC Asian Elephant Specialist Group, and Steering Committee member of Project Elephant (Government of India).

LAURA VAN DER MEER is an attorney serving as Director of International Environmental Resources in Belgium. Laura specializes in the field of international environmental law and policy, focusing on multilateral environmental agreements concerning in-situ and ex-situ conservation.
Abstract: Loss of habitat is one of the most significant problems facing elephants worldwide, leading to clashes over resources between wildlife and humans where elephants receive the largest part of blame - defined as Human Elephant Conflict (HEC). The sub-Saharan region of Africa contains an approximate population of 500,000 elephants that occupy 37 range countries. The African Elephant (Loxodonta africana) is categorized as Vulnerable in the Red List of Threatened Species; they are listed there as two distinct subspecies: the Savanna Elephant $(L$. a. africana) and the Forest Elephant (L. a. cyclotis). The Red List of Threatened Species categorizes the Asian Elephant (Elephas maximus) as endangered, and today they are found in 13 range states. The Asian Elephant population is estimated to be 30,000 to 50,000 with approximately $60 \%$ of the population being present in India. Due to threats of poaching, the elephant ivory debate has been an important part of recent meetings of the Convention on International Trade in Endangered Species of Wild Fauna and Flora (CITES) as Parties have debated proposals for one-time sales of legal government stockpiles of elephant tusks. To maintain elephant populations into the future, long-term and large-scale planning is necessary to ensure adequate space and protection for elephants and people living in elephant habitats.

\section{INTRODUCTION}

This paper presents a general overview of elephants - current populations and conservation management. We discuss the existing status of African and Asian elephants, along with an update about CITES and the ivory trade.

Elephants are one of the centerpiece species among the charismatic megafauna. They appeal to people of all ages, especially to those who do not have to live with the threats of their presence. Elephants are considered ecosystem engineers by such acts as modifying their habitat by resetting succession of a forested habitat to grassland, digging holes to access water in times of drought, and spreading the propagules of numerous plants. They also are umbrella species as the conservation of elephants can preserve vast tracts of habitats and the various species that live therein. Yet their size, intelligence, and need for space make them challenging to manage in a world of expanding human populations. Loss of habitat is one of the most significant issues facing elephants worldwide, leading to clashes over resources between wildlife and humans where elephants receive the largest part of blame - defined as Human Elephant Conflict (HEC). Poaching for ivory is rising again, putting additional pressure on elephant populations (Wasser et al. 2009).

As the largest living land mammals, elephants have attracted human attention for millennia. There are two genera of living elephants (Order Proboscidea, Family Elephantidae), the Asian Elephant (Elephas) and the African Elephant (Loxodonta). The Asian Elephant is often delineated into three sub groups, namely Indian ( $E$. maximus indicus), Sri Lankan (E. m. maximus), and Sumatran (E. m. sumatranus) forms (Sukumar 2003). A recent study using mitochondrial and microsatellite analysis indicated that a Borneo subspecies (E. m. borneensis) may be reinstated (Fernando et al. 2003). The two recognized subspecies of the African Elephant, the Forest ( $L$. africana cyclotis) and Savanna (L. africana africana), may be distinct species (Roca et al. 2001).

The conservation of any species can be aided by understanding its behavior, physiology and ecology. As a charismatic flagship and keystone species, elephants help call attention not only to their own needs but also to the requirements of other species. Thus, the conservation of elephants can promote a healthy ecosystem for a broad array of species.

\section{African Elephant Conservition}

The sub-Saharan region of the African continent contains a population of at least 550,000 elephants, with some estimates approaching 700,000 individuals in 37 range countries (Blanc et al. 2007). The Savanna Elephant resides primarily in southern and 
eastern Africa, but also in Central and West Africa. The Forest Elephant lives primarily in Central and West Africa. Recent studies in molecular genetics have proposed that these two subspecies are distinct species (Roca et al. 2001; Comstock et al. 2002; Roca et al. 2005), and there is evidence that a third West African species exists (Eggert et al. 2002). Currently, the African Elephant Specialist Group (AfESG) of the IUCN recognizes only a single species with two subspecies (Debruyne 2005; Blanc et al. 2007; Johnson et al. 2007).

Elephants are not evenly distributed across the continent. Southern Africa has the largest range $\left(39 \%\right.$ of $\left.3,335,827 \mathrm{~km}^{2}\right)$ and contains $>50 \%$ of the continental population (Blanc et al. 2007). Eastern and Central Africa have similar range sizes with Eastern Africa containing 165,000-200,000 individuals while Central Africa has 60,000-135,000 elephants. West Africa contributes some $5 \%$ of the total range and perhaps 10,000 elephants. Approximately $70 \%$ of the range of elephants lies outside of protected regions (Blanc et al. 2007). As a consumable resource for humans, elephants are hunted for their meat, hide, and ivory; elephants also serve as a renewable resource for tourism. Elephants affect ecological succession, facilitate seed dispersal and germination of many tree species, and influence the abundance of plant and animal species (Dudley 1999; O'Conner et al. 2007; Stephenson 2007; Pringle 2008). The African elephant not only serves as an ecosystem engineer, but also as a flagship species worldwide, which may offer it more protection than other species in peril (Leader-Williams \& Dublin 2000; Walpole \& Leader-Williams 2002; Caro \& Scholte 2007).

The major conservation issues for elephants are similar to those of most large mammals, namely habitat loss and fragmentation, poaching, and conflict with humans (Stephenson 2007). These issues are intimately related. As space contracts for elephants, HEC and likely the tolerance for poaching increase. The relationship between greater human numbers and fewer elephants is not linear, but above a critical number of humans $\left(15.6 / \mathrm{km}^{2}\right.$ and ca. $50 \%$ land conversion to human uses), elephants effectively disappear (Hoare \& du Toit 1999). This is likely to result from elephants emigrating and not local extinction by humans. While a variety of methods are implemented to reduce HEC locally (Parker \& Osborn 2006; Osborn 2007), land use planning and political stability are necessary for long-term coexistence between elephants and humans (Lee \& Graham 2006; Walpole et al. 2006). Habitat fragmentation or compression, as during times of drought, and poaching disrupt elephant social structure (Moss 1990, 2001; Foley 2002), and may lead to reduced genetic diversity as fewer male elephants father a greater proportion of the offspring (Ischengoma et al. 2007). Elephants may respond by coalescing into matriarchal groups that include non-related members, but the implications of this behavior for their long-term survival have not been evaluated (Nyakaana et al. 2001; Wittemyer et al. 2009).

While elephants face many of the same problems across their range, the perspectives and approaches to their management vary widely. The Red List of Threatened Species categorizes the African Elephant as vulnerable (IUCN 2006), but great variability in population stability is evident across the regions of Africa.

Southern Africa (Angola, Botswana, Malawi, Mozambique, Namibia, South Africa, Swaziland, Zambia, Zimbabwe):

Savanna Elephants are numerous in this region, although Forest Elephants may occur in Angola (Blanc et al. 2007).
Angola, Malawi, and Swaziland have small populations $(<2,500)$, while Mozambique, Namibia, South Africa, and Zambia estimates range from 15,000 to 30,000 elephants. Botswana and Zimbabwe have the largest populations with 321,000 elephants likely ( $47 \%$ of the continental total). In the $19^{\text {th }}$ century 200,000 to 400,000 elephants may have dwelled in Botswana alone, but the population appears to be leveling off at some 175,000 currently (Junker et al. 2008). Elephants in Zimbabwe have suffered from increased poaching and HEC as drought and economic depression have created problems for humans and wildlife with increases in the poaching of elephants (Blanc et al. 2007; Dunham 2008).

Elephants in South Africa reside within private reserves and national parks, which can serve as sources to repopulate areas with few or no elephants. Many wildlife populations are restricted in their movements by human activities, requiring the examination of issues related to closed populations. While elephants have an impact on species level composition, community effects are more difficult to discern (Guldemon \& van Aarde 2007), and the mechanisms of influence may be more complex than simple consumption through herbivory (Landman et al. 2007). Natural mortality may not be sufficient to control elephant numbers at levels consistent with other conservation goals (Woolley et al. 2008), thus, management options need to be tailored to the region accompanied by sound scientific monitoring (Owen-Smith et al. 2006). The option to translocate elephants for local population reduction diminishes when either people occupy what was once suitable elephant habitat, or elephant numbers in these areas grow from translocation or natural immigration. If higher population densities of elephants cannot be tolerated, then either growth must be reduced through culling or contraception (FayrerHosken et al. 2000; Delsink et al. 2006), or more space must be made available. Male and female elephants show great variation in the way that they use habitats (Shannon et al. 2006). Both sexes exhibit similar preferences for regions near water with high levels of varied vegetation, and away from people (Stokke \& du Toit 2002; Ntumi et al. 2005; Harris et al. 2008). Of course, as the human population continues to expand, such regions may be difficult to find and set aside for wildlife. Viewing elephant populations as meta-populations and creating opportunities for elephants to move in a sourceto-sink fashion may contribute to stabilizing elephant numbers and related problems regionally (van Aarde \& Jackson 2007; Chamaillé-Jammes et al. 2008). Further, a regional approach makes sense economically for species that move readily across political and geographic borders (Frank \& Maurseth 2006).

Eastern Africa (Eritrea, Ethiopia, Kenya, Rwanda, Somalia, Sudan, Tanzania, Uganda):

Most of the countries in this region have very few elephants: Eritrea, Rwanda, and Somalia contain fewer than 100 each, the Sudan a few hundred at most, Ethiopia perhaps 1,500, and Uganda about 6,500 (Blanc et al. 2007). Kenya has as many as 30,000 elephants, while Tanzania has well over 100,000 , and perhaps as many as 165,000 elephants (Blanc et al. 2007). Tanzania and Sudan account for $80 \%$ of the elephant range in this region, and Tanzania is home to $80 \%$ of the regional population (Blanc et al. 2007).

Human expansion and the resulting fragmentation of habitat are the major problems in this region since the ivory ban has been in place, although political instability in some countries leads to a low priority for the conservation of wildlife (Blanc et al. 2007). As with other regions, HEC is clearly a major issue 
(Amwata et al. 2006; Kioko et al. 2006), and Tanzania is the only country in this region with an active national elephant policy; Kenya is only now developing an elephant strategy (Blanc et al. 2007). Studies in this region highlight the variation in Savanna Elephant social structure over wet and dry seasons and the effects of season on movements (Galanti et al. 2006; Wittemyer et al. 2007). Elephants move readily across park boundaries, requiring corridors for movements and other forms of land use planning to reduce conflicts with humans (KagoroRugunda 2004; Galanti et al. 2006). The creation of such corridors could occur by the restoration of degraded rangelands, permitting the recolonization by wildlife, including elephants.

Central Africa (Cameroon, Central African Republic, Chad, Congo, Democratic Republic of Congo, Equatorial Guinea, Gabon):

The forested habitat, relatively weak infrastructure, and economic instability make determining elephant populations in this region very difficult (Blanc et al. 2007); hence, the population estimates are highly variable. Equatorial Guinea has fewer than 1,500 elephants, the Central African Republic (CAR) 2,000-3,000, and Chad 4,000-6,000 (Blanc et al. 2007). Cameroon may have as few as 1,000 or as many as 16,000 elephants (Blanc et al. 2007). Estimates for the Democratic Republic of Congo (DRC) range from 11,000 to 24,000 , and for Congo 17,000 to 22,000 . Gabon has the largest population with estimates ranging from 25,000 to 71,000 elephants (Blanc et al. 2007). Forest Elephants predominate in most of this region with Savanna Elephants limited to parts of Cameroon, CAR, and Chad.

As with other regions, habitat fragmentation and direct take by humans are the major threats to elephants. The creation of roads for logging and mineral exploration is rampant with little regional planning, and like Savanna Elephants, Forest Elephants are more likely to be found away from roads and human habitation (Blom et al. 2004; Blake et al. 2007). Central Africa is thought to be the main source of African Elephant ivory for world trade, and law enforcement there is inadequate to protect elephants (Stiles \& Martin 2002; Hunter et al. 2004). Aerial survey methods are generally inadequate in this region, so dung counts are often used (Bruen \& Hockemba 2007), and population assessment using vocalizations is under study (Payne et al. 2003). In Equatorial Guinea, Puit and Ghiurghi (2006) estimated that 700 elephants reside in Monte Alen National Park, but some $88 \%$ of potential elephant range in this country remains unexamined for elephant presence (Blanc et al. 2007).

West Africa (Benin, Burkina Faso, Côte D'Ivoire, Ghana, Guinea, Guinea Bissau, Liberia, Mali, Niger, Nigeria, Senegal, Sierra Leone, Togo):

The habitat in West Africa is a mix of tropical forest and savanna. Both Forest and Savanna Elephants were thought to range here, but one study suggests that these elephants represent a distinct taxonomic group, potentially a third species of African Elephant (Eggert et al. 2002). No country in the region contains a large and robust elephant population. Burkina Faso has the greatest number with about 5,000 elephants, with Benin and Ghana likely to have slightly over 1,000 individuals each (Blanc et al. 2007). Mali and Nigeria each contain 350-800 elephants (Blanc et al. 2007). Liberia may have as many as 1,676 elephants, but this is speculative (Blanc et al. 2007). The remaining countries all have populations that are well under 1,000 elephants, with several under 100

The elephant populations in this region are small and fragmented, leading to genetic isolation (Blanc et al. 2007). For example, a recent survey in Guinea Bissau indicted that only 4 to 10 elephants reside there between two rivers, the Corubal River in Guinea Bissau and the Kogon River in Guinea (Brugiere et al. 2006). Some $60 \%$ of elephant range in West Africa lies within protected regions, although these reserves offer limited protection (Blanc et al. 2007).

\section{Summary}

The Savanna Elephant is doing well in particular areas of Africa where management plans are in place and space is still available for large-scale movements. Long-term and largescale planning is necessary to maintain these populations and possibly to connect smaller populations through wildlife corridors. The level of human needs in the 37 range states, and hence the conflict with elephants and other wildlife, varies greatly. Elephant populations are not likely to be sustained in all of these countries, but planning at the continent level could allow the persistence of savanna, forest, and western Africa elephants by delineating viable habitat with limited human impact. Such planning must deal with differences in perspectives on the ivory trade as well as variation in the extent of HEC across the range countries.

\section{Asian Elephant Conservation}

The Red List of Threatened Species categorizes the Asian Elephant as endangered (IUCN 2006). Genetic studies suggest that while there is some differentiation between the mainland population and the Sri Lankan population (Fernando et al. 2000), the genetic divergence of Borneo elephants warrants their recognition as a separate evolutionarily significant unit (Fernando et al. 2003), thus making them a high priority population for conservation.

Today Asian Elephants are found in 13 range states with nearly $60 \%$ of the population being present in India. Other countries with reasonably large populations are Sri Lanka, Myanmar, Thailand, Malaysia, and Indonesia. Relatively smaller populations are found in Cambodia and Lao PDR. Nepal, Bangladesh, Bhutan, China, and Vietnam each have very small populations numbering a few hundred or fewer. While the Asian Elephant population is estimated to be 30,000 to 50,000 , this estimate may be flawed (AsERSM 2006) as it is largely compiled from reports from various range states (Santiapillai \& Jackson 1990). These reports are mostly based on guesses, or in a few cases on estimates using coarse population sampling methods. Even in countries with supposedly good estimates, very few areas have actually been sampled using rigorous sampling methods (AsERSM 2006). The reasons for this poor state of knowledge include difficulties estimating populations in forested habitat, lack of capacity and institutional strength, inadequate resources, lack of political will, and general apathy. Populations appear to be increasing in some areas while they are declining in other areas (AsERSM 2006). Despite poor assessment, often the scale of the problem or change is large enough to allow making a reasonable assessment of the status and general population trend.

The Asian Elephant (Elephas maximus) was once distributed from West Asia (Tigris and Euphrates River valleys) to Indochina. Today, elephants are no longer found in West Asia or even in western India. The western most populations 
are currently found in northern and southern India, and although the range still extends to Indochina in the east, only small populations persist in southern China and parts of Vietnam. The estimated original range of the Asian Elephant was 9 million $\mathrm{km}^{2}$ but it has declined to about $500,000 \mathrm{~km}^{2}$ (Sukumar 2003). While historic populations are unknown, the fact that the Moghul Emperor Jehangir (early $17^{\text {th }}$ Century) supposedly owned 12,000 elephants, and there were 40,000 captive elephants (equal to the current total wild population) in his empire suggests that large wild populations existed in the past (Olivier 1978a). Similarly, in the mid 1800s, approximately 5,500 elephants were shot over a period of 8 years in Northern and Southern Provinces of Sri Lanka, a figure much higher than the current estimated wild population for that country (Olivier 1978b). There is little doubt that the range and population have significantly declined.

Habitat loss has been largely responsible for the largescale decline of the Asian Elephant's range, and it remains a major threat to elephant conservation in Asia (Sukumar 2003, AsERSM 2006). In the last half-century or so, Asia has seen a rapid growth of its human population and development. This has accelerated habitat loss and most elephant range states have seen declines of $25 \%$ to $60 \%$ in their forest cover during this period. The problem of habitat loss has been further exacerbated by habitat fragmentation and the absence of integrated and planned development that takes into account conservation needs. Fragmentation has created smaller habitat patches often poor in habitat quality, and genetically isolated populations that are less suitable for long-term conservation. HEC has increased as fragmentation affects a greater part of the population and creates habitat patches that are inadequate for elephants. Such small, isolated populations that are in serious conflict with the surrounding human population have little hope for long-term survival, and as such, the present population figures are not indicative of what can be successfully conserved in the future.

The bulk of human population in Asia is rural (56\% to $85 \%$ ), and $33 \%$ to $81 \%$ of the population in these countries lives below the poverty line with an income of less than US\$2 a day (Population Reference Bureau 2005). Much of the remaining elephant habitat is surrounded by rural human populations that depend, to varying degrees, on these forests for their livelihood. So in addition to habitat loss and fragmentation, habitat degradation due to biotic pressure (e.g., cattle grazing, fuel wood collection, illegal logging, collection of non-timber forest produce, fires, disturbance from human presence) is a major problem throughout elephant ranges in Asia.

Habitat loss, fragmentation, and degradation are likely to remain serious threats to elephants and other wildlife as range state human populations are projected to increase substantially (39\% to 96\%) by the year 2050 (Population Reference Bureau 2005). These problems need to be addressed through integrated land use and development planning that takes conservation needs into account. Because the prospects of restoring connections among fragmented patches of habitat are unlikely, a more effective approach would be to maintain the integrity of existing habitat patches and corridors, and prevent further fragmentation. Reduction of anthropogenic pressure on the remaining habitat patches is critical and requires that people in rural populations develop alternate or enhanced sources of income and fuel, thereby reducing their forest dependency. In the long-term, reduction in human population growth, improved and planned rural development around forest habitats, and increased urbanization will benefit elephant habitat by reducing biotic pressures on the habitat.

HEC poses a serious threat to elephant conservation in Asia. The large and growing human population is creating increased competition among people. Population growth coupled with growing socio-economic aspirations, and greater awareness of better living standards and human rights, have all contributed to making people less tolerant of HEC. Retaliatory killing of elephants is becoming common and poses a serious threat to elephant conservation. In India in recent years, more HEC related elephant deaths were recorded than those due to poaching (AsERSM 2006). Sri Lanka lost 1,369 elephants in a 10-year period, mostly through HEC (Hendavitharana et al. 2004). All range states report HEC, and ten of the thirteen range states report $\mathrm{HEC}$ related retaliatory killings of elephants (AsERSM 2006). HEC not only increases the local community's hostility towards elephants, but also towards conservation in general.

Other than illegal retaliatory killings, HEC also has had other impacts on elephant populations. In Indonesia (Sumatra), capture has been used as an HEC mitigation tool (Basrul et al. 2001). Poor capture, training, and management have resulted in high mortality rates of elephants. It also has resulted in the government being burdened with the management of nearly 400 captive elephants, which have no real or productive work. The overall result has been a significant reduction of wild elephant populations in Sumatra. Similarly in Malaysia and Sri Lanka, large-scale translocation (by capture or drive) to eliminate elephants from developing areas has significantly reduced their range (e.g., Bandara \& Tisdell 2003). The whereabouts of these translocated animals is unknown as there was no monitoring. Culling of problem animals or rogues has been minimal in the last few decades, but prior to that, it was practiced in several countries where conversion of elephant habitat was leading to increased HEC.

In the past, large-scale captures for domestication and killing as a means for HEC mitigation significantly reduced elephant numbers. However, with increasing focus on conservation due to the rapid decline in habitat and elephant numbers, this approach is no longer an option. HEC needs to be managed if conservation is to succeed in Asia, and the first step would be to stop habitat loss, fragmentation, and degradation - the root causes of HEC. The major reasons for the failure of HEC mitigation measures have been public and governmental apathy, inability to take responsibility, poor understanding of HEC and elephant behavior, inability to take an adaptable approach, poor application of mitigation methods, and the inability to sustain HEC mitigation efforts (Desai 1998, 2002). The management of existing HEC situations calls for an integrated, flexible, and committed approach from all stakeholders so that the most appropriate tools are applied effectively and in a sustained manner.

Since the 1950s, poaching for ivory and other elephant products has increasingly threatened elephant populations. Poaching for ivory has resulted in extremely skewed sex ratios in southern India where the majority of males (>90\%) have tusks. Most of the older males have been killed, and the adult male to female sex ratio in Periyar National Park (Kerala state, India), which was very severely affected by poaching, was 1:122 in 1997 (Source: Project Elephant, Government of India). Similarly, in Mudumalai Wildlife Sanctuary in Tamil Nadu state, the ratio was 1:29 in 1999 (Baskaran \& Desai 2000). In other areas where there is poaching for ivory and other elephant parts (i.e. tail, hair, molars, bones, and skin), the entire 
population is affected. In Cambodia, Lao PDR, and Vietnam, elephant populations were severely depleted during the Vietnam War years and subsequently when wildlife was actively hunted for commercial purposes (for Cambodia see Desai \& Vuthy 1996). Poaching and HEC related killings also have depleted elephant populations in NE India, China, and possibly Thailand. The population in Myanmar has been adversely affected by captures for use in the timber industry (Caughley 1980; Aung 1997). Illegal captures are harmfully affecting the population in several other countries where populations are low (AsERSM 2006).

Asia remains the major market for legal and illegal ivory and other elephant products (AsERSM 2006, CITES 2008). While the global focus is on international ivory trade, the local demand (within country) and regional demand (within Asia) are sufficient to adversely affect many elephant populations due to the low number of males with tusks and the fact that other products such as tail hair, tails, molars, bones, and meat are also in demand. An international ban on ivory trade likely will not completely resolve poaching in Asia. One of the biggest problems is the rather porous border between most range states that prevent monitoring or regulating the movement of ivory and other elephant products. Poor law enforcement infrastructure and capacity, limited resources, and lack of political will allow poaching and trade in illegal ivory and other elephant products. To resolve Asia's poaching problem, improved field-based protection, tightening porous international borders among range states, and curbing illegal trade within country are essential.

A new problem that is manifesting itself in some areas is local overabundance. In some cases, this is the result of a growing elephant population, and in other cases, it is the result of compression when habitat is lost or fragmented. In southern India, Sivaganesan \& Sathyanarayana (1995) found that tree species that elephants feed on in the deciduous forests were rapidly declining due to elephant pressure. While regeneration could have been suppressed due to deer browsing and fires, the mature trees were clearly showing signs of overuse. Daniel et al. (1987) had shown that the elephant population was growing in this area despite poaching of males. By 2000, the population had nearly doubled in this area (Baskaran \& Desai 2000). The absence of studies focusing on local elephant overpopulation indicates that this issue has been largely ignored. It may become a serious problem in some areas in the near future, as it has the potential to degrade the habitat and adversely affect biodiversity, especially in areas that are already facing pressure from the surrounding human population.

Most elephant range states are developing countries with limited financial resources to commit to conservation, so funds remain a major constraint in conserving elephants. Conservation often takes a back seat with governments focusing primarily on development. Political will and public support for conservation can be generated by making people aware of the ecosystem services (watershed, moderating climate, etc.) provided by elephant habitats. Advocacy and building awareness both within and outside range states will be essential for generating increased support for protecting elephants and their habitats. Given the range of problems associated with elephant conservation, it becomes very important that scientifically sound conservation and management strategies be adopted. However, management capacity and the institutional strength of government agencies mandated with wildlife conservation need to be improved as well. One of the major limitations is the lack of good data on wild Asian Elephants, their ecology, ranging behavior, and population dynamics. In addition, the failure to use existing information in planning for conservation, HEC mitigation, and development hinders elephant conservation in Asia.

South Asia (India, Sri Lanka, Bangladesh, Nepal, and Bhutan): India, with an estimated elephant population of 26,000 to 30,000 (Source: Project Elephant, Government of India) supports over $60 \%$ of the entire Asian Elephant population. Sri Lanka is the only other country with a sizable population in this region and has an estimated 3,500 to 4,500 elephants (AsERSM 2006). Elephants in India and Sri Lanka have the best prospects for long-term conservation. Habitat loss and fragmentation, HEC, and, in the case of India, poaching are the major threats. Habitat fragmentation has created several pocketed or isolated populations that have insufficient habitat, and consequently HEC is severe in such areas. These pocketed and isolated populations may have no real longterm future. Bangladesh has a population of fewer than 250 elephants (Chakraborty 1996), mostly along its border with India and Myanmar. Nepal has fewer than 200 elephants, some of which migrate seasonally between Nepal and India (Sukumar 2003). HEC and poaching remain problems, although to a lesser extent than in India. Bhutan has about 300 elephants (Sukumar 2003) and their range includes the habitat on the Indian side too. For these countries, there is a need to manage these populations as cross-border populations as their range extends into India.

Southeast Asia (Myanmar, China, Thailand, Malaysia, Cambodia, Lao PDR, Vietnam, and Indonesia):

Peninsular Malaysia has an estimated population of 1,200 elephants (Khan 1990), while Sabah (Borneo) has an estimated population of 1,100 to 1,600 (Alfred 2002). In Indonesia, Sumatra had an estimated population of 2,800 to 4,800 in the early 1980s (Blouch \& Haryanto 1984; Blouch \& Simbolon 1985), but large scale loss of habitat due to oil palm and pulp wood plantations, coupled with large scale capture (Basrul et al. 2001) and retaliatory killing due to HEC, has severely diminished the population. Currently, fewer than 3,500 elephants are believed to inhabit Sumatra (Sukumar 2003). The population in Kalimantan (Indonesian part of Borneo) has not been estimated and surveys (source: WWF Indonesia) show that only a small population extends into Kalimantan along the border from adjoining Sabah (Malaysia). Thailand has an estimated 3,000 to 3,500 elephants (Srikrachang 1992). While Myanmar has an estimated population of over 5,000 elephants (Kemf \& Santiapillai 2000), this may be optimistic given that recent surveys indicate that elephants may be present at lower densities than previously thought (Shepherd \& Nijman 2008). Cambodia and Lao PDR have populations of about 1,000 elephants (Santiapillai \& Jackson 1990). Vietnam has fewer than 100 (Heffernan \& Cuong 2004), while China has fewer than 300 elephants (Santiapillai \& Jackson 1990).

Myanmar, Cambodia, and Lao PDR have severely depleted populations, the former due to sustained capture of elephants for their timber industry (Aung 1997), and the latter two due to hunting or poaching (Desai \& Vuthy 1996). In all three countries, large areas of good habitat remain intact, and therefore these countries retain the opportunity to increase their elephant populations through better protection and management. Poaching and illegal captures remain a serious 
problem (Shepherd \& Nijman 2008), and HEC, while present, is not very severe across these countries. However, these countries are at a stage where rapid development can start at any time and this could result in significant loss and fragmentation of the remaining elephant habitat. Therefore, suitable and adequate habitat needs to be secured for elephant conservation before it is too late, and habitat is lost or fragmented.

In recent times, Indonesia and Malaysia have witnessed some of the largest losses of elephant habitat primarily to agroforestry (acacia and oil palm plantations). This rapid conversion of large tracts of elephant habitat has reduced elephant range and brought about severe HEC, which has been addressed through translocation (Malaysia) and capture (Indonesia) programs. There also have been legal and illegal killings of elephants as a means to reduce HEC (AsERSM 2006). Fernando et al. (2003) identify the Borneo elephant population as an evolutionarily significant unit, making its conservation a high priority. Currently in Borneo, Malaysia is struggling to strike a balance between conservation and development (oil palm plantations). Recent trends indicate that only a small fraction of the original elephant habitat and population is likely to be secured in the long term, given the rapid growth and expansion of the agroforestry industry.

China is focusing on trying to save what little remains of their elephant habitat and population. The major threats are HEC and poaching. Vietnam, with a very small and fragmented population, also faces the problem of poaching, HEC, and habitat loss. The trends are worrying: the population has declined from an estimated 1,500 and 2,000 (Khoi 1988) in the 1980s, to between 400 and 600 (Dawson et al. 1993) in the 1990s and in recent years to fewer than 100 (Heffernan \& Cuong 2004). Vietnam may become the first country in Asia in recent times to lose its elephant population unless there is a major effort to protect the remaining population.

\section{Summary}

Based on present trends, it is likely that the Asian Elephant will survive in most range countries; some countries like Malaysia, Indonesia, and Sri Lanka may lose some of their elephants before conservation efforts stabilize the populations and habitats. Prospects for saving large habitat patches exist in countries like Myanmar, Cambodia, and Lao PDR, however it remains to be seen if this will happen and elephants can regain sustainable densities. Countries with smaller populations such as Bhutan, Nepal, Bangladesh, and China will likely retain their populations if the current level of concern and action remains intact. Yet, they will need to address crossborder issues such as free movement of elephants across common borders, HEC, and poaching to ensure that their populations survive in the long term. India will remain the major stronghold for Asian Elephants, although a number of small isolated populations are likely to be lost due to poor and inadequate habitat, and to severe HEC. Only in Vietnam does the continued survival of the elephant remain in doubt in the near future.

\section{Elephant Ivory Trade: Limited Trade Approved after Six- Year Process}

In 2002, the African Elephant ivory debate took center stage in meetings of the Convention on International Trade in Endangered Species of Wild Fauna and Flora (CITES). At this meeting Parties agreed to proposals from three countries for one-time sales of government stockpiles of tusks removed from elephants that died of natural causes or were culled. The sale, consisting of 20 tons from Botswana, 10 tons from Namibia, and 30 tons from South Africa, was subject to three conditions:

1. Sales could only be made to trading partners that have been verified by the CITES Secretariat, in consultation with its Standing Committee, to have sufficient national legislation and domestic controls to ensure that the imported ivory will not be re-exported and will be managed in accordance with all relevant requirements;

2. Baseline information must be reported by the Monitoring the Illegal Killing of Elephants (MIKE) program; and

3. The Standing Committee must agree that all conditions are met.

In 2003, the Standing Committee agreed that baselines would be established through research at a representative selection of sites and on the basis of:

* At least one population survey per site;

* Levels of illegal killing derived from 12 months of data in Africa and 6 months of data in Asia;

* A descriptive report of influencing factors (including changes in legal or judicial system, land use changes, etc.);

* An assessment of the efforts made to compile the information; and

* A preliminary baseline founded on the above information.

The Standing Committee also agreed that no data older than 3 years would be used and that all data would be peer reviewed.

At the next meeting of the CITES Parties in 2004, South Africa and Namibia slightly expanded their existing approvals concerning elephant trade. In the case of South Africa, the revised decision allows for trade in leather goods for commercial purposes. Namibia gained acceptance of its proposal for trade in leather and hair goods, as well as the non-commercial use of worked ivory.

In the meantime, the MIKE program began operations and the collection of data to establish baseline information to allow for the one-time sale of the ivory stockpiles agreed to in 2002. In 2005, however, a gap in funding threatened the continuation of the work pending receipt of funds available from the European Union in early 2006. This problem was resolved through donations by the United Kingdom, Japan, The Netherlands, South Africa, and the International Elephant Foundation. By 2006, MIKE work was completed or nearing completion for all 45 sites in Africa, and for most of the 18 sites in Asia (MIKE 2007). In 2007, the Standing Committee agreed that the baseline information was in place, clearing one of the hurdles for the one-time sale. Concerning the other condition, namely, the designation of trading partners, the Standing Committee approved Japan. China's candidacy failed, but in July 2008, it was reconsidered and approved at a meeting of the Standing Committee.

Accordingly, by the meeting of the CITES Parties in 2007, all the conditions were in place for the one-time sale to take place; however a number of new proposals were brought to the Parties for consideration. These included proposals from Botswana, Namibia, South Africa, and Zimbabwe to establish annual quotas for the sale of ivory, with the proceeds to be used for conservation. Botswana also sought approval for another one-time large-scale sale, and to allow trade in hunting trophies, hides, and leather goods for commercial purposes, and trade in live animals for commercial purposes to 
"appropriate and acceptable destinations". In addition, Tanzania sought to join the other countries by requesting approval for trade of registered ivory stocks, export of live specimens for non-commercial purposes, and trade in hunting trophies for non-commercial purposes. Kenya and Mali, on the other hand, opposed the proposed elephant trade and sought the adoption of decisions that would prohibit trade in raw or worked ivory for 20 years, except non-commercial hunting trophies and the 2002 agreed sales.

After many hours of negotiations among the African countries, delegates emerged with a compromise: in the final deal, which all the CITES Parties accepted, trade in hunting trophies, hide, hair, and leather goods were approved for the elephant populations of South Africa, Namibia, Botswana, and Zimbabwe. Trade in live animals is allowed to "appropriate and acceptable destinations" (a term defined in a CITES resolution) for Botswana and Zimbabwe; and trade in live animals for in situ conservation programs is allowed for South African and Namibian populations.

Concerning ivory, all government stockpiles registered as of January 2007 (including the quantities agreed in 2002 for a one-time sale) will be allowed to be sold to verified trading partners following Secretariat verification of registered stocks. This will occur in a single sale per destination under the supervision of the Secretariat. All proceeds must be used for elephant and community conservation and development programs within or adjacent to elephant ranges.

An important element of the consensus was that a "resting period" would now take place for a period of nine years. This means that no further proposals concerning ivory trade from populations from the four African countries will be considered during this time. In the future, the CITES Parties will work to create a mechanism for consideration of ivory issues to avoid delays and undue expenditure of time on a single issue at CITES meetings.

A final part of the package included a decision to establish a fund to implement an Elephant Action Plan, including continued operation of the MIKE program. It was agreed that the CITES Secretariat will establish a steering committee consisting of representatives from elephant range countries and donors to govern the fund and advise on implementation of the Action Plan.

\section{Conclusion}

African and Asian elephants in the wild can be sustained over the majority of their current range with the continuation of protection, research, planning, and reduction of humanelephant conflict. A regional approach that extends beyond the borders of individual countries is necessary for their longterm survival. Asian Elephants are in a more precarious situation than African Elephants because of much lower numbers in smaller populations, less data on their biology in the wild, and greater interaction with humans who occur in higher densities than in Africa. The recent initiatives by CITES to fund the Elephant Action Plan and the implementation of a nine year resting period for the trade of ivory will facilitate improved management of wild populations. Adequate space and protection are vital for the survival of any species. HEC can have serious negative consequences for the elephant species; thus, the prevention of unwanted interaction is a primary objective of HEC mitigation (WWF 2008). The conservation goal should be to use all of the available information and resources to ensure the long-term survival of African and Asian elephants.

\section{Appendix}

Further information about elephant conservation can be found on these websites:

The International Union for Conservation of Nature and Natural Resources (IUCN): www.iucn.org

The IUCN-SSC African Elephant Specialist Group (AfESG):

www.iucn.org/themes/ssc/sgs/afesg

The IUCN-SSC Asian Elephant Specialist Group (AsESG):

www.asesg.org

The Convention on International Trade in Endangered Species of Wild Fauna and Flora (CITES): www.cites.org

The US Fish and Wildlife Service International Affairs African Elephant Conservation Fund Program:

http://www.fws.gov/international/DIC/species/afe/ african_elephant.html

The US Fish and Wildlife Service International Affairs Asian Elephant Conservation Fund Program:

http://www.fws.gov/international/DIC/species/ase/ asian_elephant.html

\section{References}

Alfred, R.J. (2002). Summary report on the status and distribution of Asian elephant in Sabah. WWF Malaysia, Malaysia.

Amwata, D.A., P. Omondi \& E. Bitok (2006). Human-wildlife conflict in Mochongoi Forest, Baringo, Kenya: a case study of elephants. Pachyderm 41: 30-36.

AsERSM (2006). Asian Elephant Range States Meeting, January 2006, Kuala Lumpur, Malaysia. IUCN-SSC Report.

Aung, M. (1997). On the distribution, status and conservation of wild elephants in Myanmar. Gajah 18: 47-55.

Bandara, R. \& C. Tisdell (2003). Comparison of rural and urban attitudes to the conservation of Asian elephants in Sri Lanka: empirical evidence. Biological Conservation, 110, 327-342.

Baskaran, N. \& A.A. Desai (2000). Elephant population estimation in Mudumalai Wildlife Sanctuary and National Park (Wildlife Division, Ooty). Report 1999-2000. Bombay Natural History Society and Tamil Nadu Forest Department.

Basrul, A., M. Hambal \& H.R. Sadjudin (2001). The role and strategy of elephant training centres in human elephant conflict mitigation. FFI-SECP, Banda Aceh, Indonesia.

Blake, S., S. Strindberg, P. Boudjan, C. Makombo, I.O. Bila-Isial, F. Grossmann, L. Bene-Bene, B. de Semboli, V. Mbenzo, D. S'hwa, R. Bayogo, L. Williamson, M. Fay, J. Hart \& F. Maisels (2007). Forest elephant crisis in the Congo. PLoS Biology 5(4): e111. Doi:10.1371 / journal.pbio.0050111

Blanc, J.J., R.F.W. Barnes, G.C. Craig, H.T. Dublin, C.R. Thouless, I. Douglas-Hamilton \& J.A. Hart (2007). African elephant status report 2007: an update from the African elephant database. Occasional Paper Series of the IUCN Species Survival Commission, NO. 33. IUCN/SSC African Elephant Specialist Group. IUCN, Gland, Switzerland.

Blom, A., R. van Zalinge, E. Mbea, I.M.A. Heitkönig \& H.H.T. Prins (2004). Human impact on wildlife populations within a protected Central African forest. African Journal of Ecology 42: 23-31.

Blouch, R.A. \& Haryanto (1984). Elephants in southern Sumatra. IUCN/WWF Report No. 3. Project 3033. Bogor, Indonesia.

Blouch, R.A. \& K. Simbolon (1985). Elephants in northern Sumatra. IUCN/WWF Report No. 9. Project 3033. Bogor, Indonesia.

Bruen, T. \& M.N. Hockemba (2007). Forest elephant dung decay in Ndoki Forest, northern Congo. Pachyderm 43: 43-51.

Brugerie, D., I. Badjinca, C. Silva, A. Serra \& M. Barry (2006). On the road to extinction? The status of elephant Loxodonta africana in Guinea Bissau and western Guinea, West Africa. Oryx 40: 442-446.

Caro, T. \& P. Scholte (2007). When protection falters. African Journal of Ecology 45: 233-235. 
Caughley, G. (1980). Comments on elephants in Burma FAO (RAPA), Bangkok. Reprinted in Gajah 14: 1-9.

Chakraborty, T.R. (1996). Ecology and conservation of Asian elephant, Elephas maximus, in Bangladesh. Unpubl. MSc thesis, Jahangirnagar University, Bangladesh.

Chamaillé-Jammes, S., H. Fritz, M. Valeix, F. Murindagomo \& J. Clobert (2008). Resource variability, aggregation and direct density dependence in an open context: the local regulation of an African elephant population. Journal of Animal Ecology 77: 135144.

CITES (2008). Convention on the International Trade in Endangered Species of Wild Fauna and Flora. http://www.cites.org/eng/cop/ 13/docs/E13-29-1A.pdf

Comstock, K.E., N. Georgiadis, J. Pecon-Slattery, A.L. Roca, E.A. Ostrander, S.J. O'Brien \& S.K. Wasser (2002). Patterns of molecular genetic variation among African elephant populations. Molecular Ecology 11: 2489-2498.

Daniel, J.C., A.A. Desai, N. Sivaganesan \& S.R. Kumar (1987). The study of some endangered species of wild life and their habitat - The Asian Elephant Report: October 1985 to September 1987. Bombay Natural History Society, Bombay.

Dawson, S., Do Tuoc, Le Vu Khoi \& T.V. Cuong (1993). Elephant surveys in Vietnam. Project VN 0005. WWF Indochina Programme, Hanoi, Vietnam.

Debruyne, R. (2005). A case study of apparent conflict between molecular phylogenies: the interrelationships of African elephants. Cladistics 21: 31-50.

Delsink, A.K., J.J. van Altena, D. Grobler, H. Bertschinger, J. Kirkpatrick \& R. Slotow (2006). Regulation of a small, discrete African elephant population through immunocontraception in the Makalali Conservancy, Limpopo, South Africa. South African Journal of Science 102: 403-405.

Desai, A.A. (2002). Design of human-elephant conflict mitigation strategy for the proposed Tesso Nilo Protected Area, and possible expansion of such strategy into the Tesso Nilo Conservation Landscape, and the Province of Riau. Draft, Jakarta, Indonesia: WWF-Indonesia.

Desai A.A., (1998). Technical Report: Management Strategies for the Conservation of Elephants and Mitigation of Human-Elephant Conflict. GEF Project, FAO. Colombo, Sri Lanka.

Desai, A.A. \& L. Vuthy (1996). Status and distribution of large mammals in northeastern Eastern Cambodia: results of the first foot surveys in Mondulkiri and Ratanakiri Provinces. IUCN/FFI/ WWF Large Mammal Conservation Project, Phnom Penh, Cambodia.

Dudley, J. (1999). Seed dispersal of Acacia erioloba by African bush elephants in Hwange National Park, Zimbabwe. African Journal of Ecology 37: 375-385.

Dunham, K.M. (2008). Detection of anthropogenic mortality in elephant Loxodonta africana populations: a long-term case study from the Sebungwe region of Zimbabwe. Oryx 42: 36-48.

Eggert, L.S., C.A. Rasner \& D.S. Woodruff (2002). The Evolution and Phylogeography of the African Elephant (Loxodonta africana), Inferred from Mitochondrial DNA Sequences and Nuclear Microsatellite Markers. Proceedings of the Royal Society Biological Sciences, 269, 1993-2006.

Fayrer-Hosken, R.A., D. Grobler, J.J. van Altena, H.J. Bertschinger \& J.F. Kirkpatrick (2000). Immunocontraception of African Elephants: a humane method to control elephant populations without behavioural side effects. Nature 407: 149.

Fernando, P., T.N. Vidya, J. Payne, M. Stuewe, G. Davison, R.J. Alfred, P. Andau, E. Bosi, A. Kilbourn \& D.J. Melnick (2003). DNA analysis indicates that Asian Elephants are native to Borneo and are therefore a high priority for conservation. PLOS Biology 1(1): E6.

Fernando, P., M.E. Pfrender, S.E. Enclada \& R. Lande (2000). Mitochondrial DNA variation, phylogeography and population structure of the Asian Elephant. Heredity 84: 362-372.

Foley, C.A.H. (2002). The Effects of Poaching on Elephant Social System. PhD dissertation, Princeton University.

Frank, B. \& P.B. Maurseth (2006). The spatial econometrics of elephant population change: a note. Ecological Economics 60:
320-323.

Galanti, V., D. Preatoni, A. Martinoli, L.A. Wauters \& G. Tosi (2006). Space and habitat use of the African Elephant in the Tarangire-Manyara ecosystem, Tanzania: implications for conservation. Mammalian Biology 71: 99-114.

Guldemon, R. \& R. van Aarde (2007). The impact of elephants on plants and their community variables in South Africa's maputaland. South African Journal of Ecology, 45: 327-335.

Harris, G.M., G.J. Russell, R.I. van Aarde \& S.L. Pimm (2008). Rules of habitat use by elephants Loxodonta africana in Southern Africa: insights for regional management. Oryx 42: 66-75.

Heffernan, P.J. \& T.V. Cuong (2004). A Review of the Conservation Status of the Asian Elephant in Vietnam. Fauna and Flora International Indochina Elephant Programme, Cambridge, UK.

Hendavitharana, W., M. Amararathne \& C. Santiapillai (in press). An assessment of the human-elephant conflict in Sri Lanka. Current Science (under review).

Hoare, R.E. (1999). Determinants of human-elephant conflict in a land-use mosaic. The Journal of Applied Ecology 36: 689-700.

Hoare, R.E. \& J.T. du Toit (1999). Coexistence between people and elephants in African savannas. Conservation Biology 13: 633639.

Hunter, N., E. Martin \& T. Milliken (2004). Determining the number of elephants required to supply current unregulated ivory markets in Africa and Asia. Pachyderm 36: 116-128.

Ishengoma, D.R.S., A.M. Shedlock, C.A.H. Foley, L.J. Foley, S.K. Wasser, S.T. Balthazary \& B.M. Mutayoba (2007). Effects of Poaching on Bull Mating Success in a Free Ranging African Elephant (Loxodonta africana) Population in Tarangire National Park, Tanzania. Conservation Genetics, 10.1007/s10592-0079332-0.

IUCN (2006). The IUCN Red List of Threatened Species. IUCN, Gland, Switzerland.

Johnson, M.B., S.L. Clifford, B. Goossens, S. Nyakaana, B. Curran, L.J.T. White, E.J. Wickings \& M.W. Bruford (2007). Complex phylogeographic history of central African forest elephants and its implications for taxonomy. BMC Evolutionary Biology 7: 244.

Junker, J., R.J. van Aarde \& S.M. Ferreira (2008). Temporal trends in elephant Loxodonta africana numbers and densities in northern Botswana: is the population really increasing? Oryx 42: 58-65.

Kagoro-Rugunda, G. (2004). Crop raiding around lake Mburo National Park, Uganda. African Journal of Ecology 42: 32-41.

Kemf, E. \& C. Santiapillai (2000). Asian Elephants in the Wild. A WWF species status report. WWF International, Gland, Switzerland.

Khan, M. (1990). The Asian Elephant: an action plan for its conservation. Newsletter of the IUCN/SSC Asian Elephant Specialist Group 11: 51-53.

Khoi, Le Vu. (1988). Some biological characteristics of elephant and elephant domestication in Vietnam. In: Proceedings of the IUCN/ SSC Asian Elephant Specialist Group Meeting. January 1988. Chiangmai, Thailand.

Kioko, J., J. Kiringe \& P. Omondi (2006). Human-elephant conflict outlook in the Tsavo-Amboseli ecosystem, Kenya. Pachyderm 41: 53-60.

Landman, M., G.I.H. Kerley \& D.S. Schoeman (2008). Relevance of elephant herbivory as a threat to important plants in the Addo Elephant National Park, South Africa. Journal of Zoology 274: 5158.

Leader-Williams, N. \& H.T. Dublin (2000). Charismatic megafauna as 'Flagship Species', pp. 53-81. In: Entwistle, A. \& N. Dunstone (eds.). Priorities for the Conservation of Mammalian Diversity: Has the Panda had its Day? Cambridge: Cambridge University Press.

Lee, P.C. \& M.D. Graham (2006). African Elephants Loxodonta africana and human-elephant interactions: implications for conservation. International Zoo Yearbook 40: 9-19.

MIKE (2007). Monitoring the Illegal Killing of Elephants (MIKE). Convention on the international trade in endangered species of wild fauna and flora. http://www.cites.org/eng/prog/MIKE

Moss, C.J. (2001). The demography of an African Elephant (Loxodonta 
africana) population in Amboseli, Kenya. Journal of Zoology 255: 145-156.

Moss, C.J. (1990). Elephants in Tarangire. Pachyderm 13: 26-30.

Naughton, L., R. Rose \& A. Treves (1999). The Social Dimensions of Human-Elephant Conflict in Africa: a Literature Review and Case Studies from Uganda and Cameroon. A Report to the African Elephant Specialist, Human-Elephant Task Force of the IUCN, Switzerland.

Ntumi, C.P., R.J. van Aarde, N. Fairall \& W.F. de Boer (2005). Use of space and habitat by elephants (Loxodonta africana) in the Maputo Elephant Reserve, Mozambique. South African Journal of Wildlife Research 35: 139-146.

Nyakaana, S., E.L. Abe, P. Arctander \& H.R. Siegismund (2001). DNA evidence for elephant social behaviour breakdown in Queen Elizabeth National Park, Uganda. Animal Conservation 4: 231237.

O'Connor, T.G., P.S. Goodman \& B. Clegg (2007). A functional hypothesis of the threat of local extirpation of woody plant species by elephant in Africa. Biological Conservation 136: 329-345.

Olivier, R. (1978a). Distribution and status of the Asian Elephant. Oryx 14: 379-424

Olivier, R. (1978b). On the Ecology of the Asian Elephant. PhD Thesis, University of Cambridge.

Osborn, F.V. (2007). Capsicum oleoresin as an elephant repellent: field trials in the communal lands of Zimbabwe. Journal of Wildlife Management 66: 674-677.

Owen-Smith, N., G.I.H. Kerley, B. Page, R. Slotow \& R.J. van Aarde (2006). A scientific perspective on the management of elephants in the Kruger National Park and elsewhere. South African Journal of Science 102: 389-394.

Parker, G.E. \& F.V. Osborn (2006). Investigating the potential for chilli capsicum spp. to reduce human-wildlife conflict in Zimbabwe. Oryx 40: 343-346.

Payne, K., M. Thompson \& Kramer (2003). Elephant calling patterns as indicators of group size and composition: the basis for an acoustic monitoring system. African Journal of Ecology 41: 99107.

Pringle, R.M. (2008). Elephants as agents of habitat creation for small vertebrates at the patch scale. Ecology 89: 26-33.

Puit, M. \& A. Ghiurghi (2006). Première Estimation de la Densité d'Eléphants dans le Parc National de Monte Alen, Guinée Equatoriale. Pachyderm 41: 44-52.

Roca, A.L., N. Georgiadis \& S.J. O'Brien (2005). Cytonuclear genomic dissociations in African Elephant species. Nature Genetics 37: 96-100.

Roca, A.L., N. Georgiadis, J. Pecon-Slattery \& S.J. O’Brien (2001). Genetic evidence for two species of elephant in Africa. Science 293: 1473-1477.

Santiapillai C. \& P. Jackson (1990). The Asian Elephant: an Action Plan for its Conservation. IUCN - The World Conservation Union, Gland, Switzerland.

Shannon, G., B.R. Page, K.J. Duffy \& R. Slotow (2006). The consequences of body size dimorphism: are African Elephants sexually segregated at the habitat scale? Behaviour 143: 11451168.

Shepherd, C.R. \& V. Nijman (2008). Elephant and Ivory Trade in Myanmar. TRAFFIC Southeast Asia, Petaling Jaya, Malaysia.

Srikrachang, M. (1992). Asian Elephant conservation in Thailand. In: Santiapillai, C. (ed.). Proceedings of Asian Elephant Specialist Group Meeting, Bogor, Indonesia.

Stephenson, P.J. (2007). WWF Species Action Plan: African Elephant, 2007-2011. WWF, Gland, Switzerland.

Stiles, D. \& E. Martin (2002). The trade in african and asian ivory in south and south east Asia. Pachyderm 33: 74-87.

Stokke, S. \& J.T. Du Toit (2002). Sexual segregation in habitat use by elephant in Chobe National Park, Botswana. African Journal of Ecology, 40: 360-371.

Sukumar, R. (2003). The Living Elephants: Evolutionary Ecology, Behavior and Conservation. New York, Oxford University Press.

Treydte, A.C., P.J. Edwards \& W. Suter (2005). Shifts in native ungulate communities on a former ranch in Tanzania. African Journal of Ecology 43: 302-311.

van Aarde, R.J. \& T.P. Jackson (2007). Megaparks for metapopulations: addressing the causes of locally high elephant numbers in southern Africa. Biological Conservation 134: 289297.

van Aarde, R.J., T.P. Jackson \& S.M. Ferreira (2006). Conservation science and elephant management in southern Africa. South African Journal of Science 102: 385-388.

Venter, F.J., R.J. Naiman, H.C. Biggs \& D.J. Pienaar (2008). The evolution of conservation management philosophy: science, environmental change and social adjustments in Kruger National Park. Ecosystems 11: 173-192.

Walpole, M.J. \& N. Leader-Williams (2002). Ecotourism and flagship species in conservation. Biodiversity and Conservation 11: 543547.

Walpole, M., N. Sitati, B. Stewart-Cox, L. Niskanen \& P.J. Stephenson (2006). Mitigating human-elephant conflict in Africa: a lesson-learning and network development meeting. Pachyderm 41: 95-99.

Wasser, S.K., Clark, B. and Laurie, C. (2009). The ivory trail. Scientific American 301: 68-76.

Wittemyer, G., W.M. Getz, F. Vollrath \& I. Douglas-Hamilton (2007). Social dominance, seasonal movements, and spatial segregation in African elephants: a contribution to conservation behavior. Behavioral Ecology and Sociobiology 61: 1919-1931.

Wittemyer, G., J.B.A. Okello, H.B. Rasmussen, P. Arctander \& S. Nyakaana (2009). Where sociality and relatedness diverge: the genetic basis for hierarchical social organization in African Elephants. Proceedings of the Royal Society Biological Sciences, doi: $10.1098 / \mathrm{rspb} .2009 .0941$.

WWF (2008). Common Ground: Solutions for Reducing the Human, Economic and Conservation Costs of Human Wildlife Conflict. Species Programme, WWF International, Switzerland.

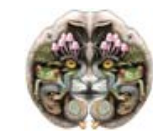

